\title{
WSPOMNIENIE O OJCU ROMUALDZIE GUSTAWIE OFM Bern. DYREKTORZE BIBLIOTEKI UNIWERSYTECKIEJ KUL W LATACH 1950-1976
}

Dzisiejsza uroczystość, zorganizowana przez J.M. Rektora KUL i Panią Dyrektor Biblioteki Uniwersyteckiej KUL, przy pomocy współpracowników, jest ważnym wydarzeniem w życiu Uniwersytetu i Biblioteki KUL. Przywołuje ona pamięć o dyrektorze Biblioteki Uniwersyteckiej KUL o. Romualdzie Gustawie, przez złożenie Mu hołdu w postaci wykonania i wmurowania upamiętniającej go płaskorzeźby wykonanej w brązie, w nowej Czytelni Teologiczno-Filozoficznej, w czterdziestą rocznicę Jego śmierci. Przygotowano również konferencję naukową i okolicznościową wystawę oraz zaplanowano wieczór wspomnień o dyrektorze ${ }^{1}$.

Po śmierci dyrektora, kierownictwo Biblioteki KUL i pracownicy myśleli o ufundowaniu tablicy ku jego czci i wydaniu drukiem materiałów z konferencji pt. Problemy współczesnej biblioteki naukowej, która odbyła się w pierwszą rocznicę śmierci. Z powodu licznych trudności, zamiaru tego nie zrealizowano, ale pamiecć o pracy i zasługach dyrektora trwała w Bibliotece KUL.

Dyrektor o. R. Gustaw był człowiekiem ogromnej wiedzy w zakresie bibliotekoznawstwa i historii książki, ale przede wszystkim był wielkim praktykiem bibliotekarstwa. Często nam, pracownikom Biblioteki KUL, przypominał, że biblioteka to książki, pracownicy, gmach i czytelnicy oraz że każda biblioteka jest i powinna być żywym i rozwijającym się organizmem. O. Gustaw był dyrektorem bardzo pracowitym, wymagającym oraz oczekującym zaangażowania w pracy od personelu biblioteki, ale też życzliwym dla pracowników. Czasami upominał lub dziękował, jak również przepraszał.

* Franciszek Chwalewski - emerytowany starszy kustosz Biblioteki Uniwersyteckiej KUL; odznaczony medalem „Za zasługi dla KUL”.

${ }^{1}$ Tekst tego wspomnienia w dużej części był wygłoszony w Bibliotece KUL w dniu 29 lutego 2016 r., po uroczystościach związanych z odsłonięciem płaskorzeźby upamiętniającej Dyrektora o. Romualda Gustawa w 40. rocznicę jego śmierci. 
W ramach naszego spotkania okolicznościowego pragnę powiedzieć, w wielkim skrócie, o działalności i troskach dyrektora, których byłem świadkiem, przez wiele lat mojej pracy w Bibliotece. Rozpocząłem ją w roku 1954 jako stypendysta biblioteczny. W roku 1955 zostałem zatrudniony na etacie bibliotekarza.

Chcę wspomnieć najpierw o działalności wystawienniczej Biblioteki KUL, inspirowanej przez dyrektora, następnie o ogromnych jego zasługach w zakresie gromadzenia zbiorów i ich udostępniania, a przede wszystkim o jego staraniach o gmach i pełną adaptację budynku, uwzględniającą potrzeby biblioteki uniwersyteckiej.

W sierpniu 1954 roku z okazji wakacyjnych wykładów dla duchowieństwa z całej Polski, które odbywały się na KUL, o. Gustaw zorganizował wielką wystawę mariologiczną w gmachu uniwersytetu, w setną rocznicę ogłoszenia dogmatu o Niepokalanym Poczęciu Matki Bożej. Byłem proszony o pomoc techniczną przy wykonywaniu podpisów pod wyłożonymi na stołach książkami i czasopismami oraz o pełnienie dyżurów. Chętnie zgodziłem się, nie przypuszczając, że ta pomoc, obok wielkiego przeżycia i spotkania z książką i osobami zwiedzającymi wystawę, przede wszystkim księżmi, w jakimś stopniu będzie miała wpływ na moją pracę w bibliotece, a więc na niemal moje całe życie. Dziękując Panu Bogu za możliwość uczestniczenia w tej maryjnej wystawie, wydaje mi się, że można przywołać słowa z książki-wspomnień abpa A. Nossola, profesora KUL, że „przypadki to logika Boga”.

Podobne wystawy z okazji zjazdów i wykładów wakacyjnych dla duchowieństwa z całej Polski były organizowane przez o. Gustawa w kolejnych latach.

W roku 1955 odbyła się wielka wystawa katechetyczna, w roku 1956 wystawa biblijna, w roku 1957 wystawa hagiograficzna, pod tytułem Święci Polscy, w roku 1958 wystawa z okazji 40-lecia KUL, w roku 1966 wystawa z okazji Millenium Polski, pod tytułem: Dzieje diecezji w Polsce. W międzyczasie były organizowane systematycznie liczne wystawy tematyczne w budynku Biblioteki KUL, przy czynnym udziale dyrektora.

Z okazji uroczystości 50-lecia KUL w 1968 roku o. R. Gustaw był inicjatorem i współtwórcą wielkiej wystawy jubileuszowej. Powołany został zespół pracowników biblioteki, składający się z około 10 osób, przygotowujący tę wystawę na dzień głównych uroczystości (19 X 1968). Zostałem również powołany na komisarza wystawy, co łączyło się z licznymi obowiązkami. Dla potrzeb wystawy wykonano 60 gablot i około 70 dużych plansz, co wiązało się ze znacznymi trudnościami technicznymi. Na wystawę tę zostało wykorzystane całe pierwsze piętro głównego gmachu KUL. Zatrudnieni byli również dwaj plastycy lubelscy: Ryszard Lis i Adam Styka. Fotografie wykonali Maria i Jan Koziołowie z pracowni mikrofilmowej Biblioteki Uniwersyteckiej KUL, którą w roku 1959 zorganizował o. Gustaw, uzyskując nowoczesny sprzęt zakupiony przez Fundację Forda. Planując tę wystawę, nie uwzględniono terminu wakacyjnych wykładów dla duchowieństwa. W związku z tym dyrektor zdecydował się na wcześniejsze nieoficjalne otwarcie wystawy w dniu 21 sierpnia 1968 roku. Odbyło się ono pomimo trudności, gdyż część prac, szczególnie plastycznych, trzeba było wykonać w godzinach wieczornych, a nawet nocnych (w tym w nocy najazdu wojsk Ukła- 
du Warszawskiego na Czechosłowację). Wystawa ta była wielkim wydarzeniem w życiu KUL i miasta Lublina. Zwiedziło ją wielu pracowników uczelni, absolwentów i studentów, uczestniczących w uroczystościach jubileuszowych.

W roku 1972 o. Gustaw podjął decyzję o zorganizowaniu w nowym pomieszczeniu Czytelni Głównej na IV piętrze, jeszcze przed przekazaniem sali dla potrzeb czytelników, wielkiej wystawy kopernikańskiej z okazji 500-lecia urodzin Mikołaja Kopernika, ponieważ w KUL odbywało się sympozjum naukowe, z udziałem uczonych i gości z różnych ośrodków naukowych. Dużo pracy włożył w przygotowanie do tej wystawy nowo mianowany wicedyrektor Biblioteki KUL - Andrzej Paluchowski. Oprawę plastyczną wykonał Leszek Mądzik, historyk sztuki KUL, a fotografie Jan Kozioł. W pracach tych pomagałem jako kierownik Czytelni Głównej oraz z tytułu pełnienia obowiązków intendenta Biblioteki KUL.

Wystawa pt. Mikołaj Kopernik (1473-1543) była bardzo interesująca, gdyż zawierała ciekawe eksponaty i duże plansze fotograficzne, obrazujące życie i działalność astronoma. Czynna była ponad miesiąc, codziennie w godzinach 8-20, a w niedzielę 10-16. Informacje o wystawie były przekazywane przez prasę lubelską, co było wówczas wielką rzadkością. Zwiedziło ją wiele grup młodzieży zorganizowanej ze szkół podstawowych i licealnych, a także studenci oraz osoby indywidualne.

Dyrektor, przez organizowanie licznych wystaw chciał pokazać wielką wartość zgromadzonych przez Bibliotekę KUL zbiorów oraz podziękować Kościołowi i społeczeństwu za okazywaną pomoc i troskę o Katolicki Uniwersytet Lubelski.

Organizowanie wystaw, o których mówiłem, było tylko marginesem wszechstronnej działalności o. Gustawa. Pamiętał, że głównym zadaniem biblioteki jest gromadzenie odpowiednich zbiorów oraz ich przechowywanie, opracowanie i udostępnianie czytelnikom. W gromadzeniu książek był bardzo zaangażowany w różny sposób. W latach pięćdziesiątych, w pierwszej kolejności, korzystał z darów, wybierając książki z tzw. Zbiornic Księgozbiorów Zabezpieczonych na Śląsku. Po uzyskaniu odpowiedniej zgody Ministerstwa i Biblioteki Narodowej często osobiście lub w towarzystwie ks. prof. M. Żywczyńskiego oraz kustosza Jana Wiślińskiego jeździł do składnic i wyszukiwał tam publikacje przydatne dla potrzeb Biblioteki KUL i służące pracy naukowej uniwersytetu. Były to czynności uciążliwe, ale z tych darów biblioteka uzyskała wiele cennych pozycji. Aktywność dyrektora budziła uznanie w wielu kręgach bibliotekarskich w Polsce, ale były też słowa krytyczne. Kiedy w 1960 roku byłem służbowo w Bibliotece Uniwersyteckiej we Wrocławiu, w rozmowie z dyrektorem prof. Antonim Knotem usłyszałem słowa, że o. Gustaw, korzystając ze zbiornic, uprzedził inne biblioteki i zabrał do Lublina (jako „szabrownik”) zbiory, które powinny pozostać na Śląsku.

W roku 1962 Biblioteka KUL zakupiła duży księgozbiór bibliofila warszawskiego Tadeusza Sterzyńskiego. W lutym wyjechaliśmy z dyrektorem i magazynierami bibliotecznymi: Józefem Todorowskim i Stefanem Tkaczykiem, samochodem ciężarowym do Warszawy. Dojazd do domu, gdzie mieścił się księgozbiór, był niemożliwy z powodu rozkopania jezdni. Trzeba więc było wjechać 
od strony ogrodu, a stąd odległość do pokonania przy załadowaniu książek była duża. o. Gustaw nie zważając na zimno i trudne warunki atmosferyczne, zdjął swój habit, założył stary kożuch i pomagał ładować księgozbiór do ciężarówki, dbając o to, żeby nie uszkodzić książek.

Dyrektor gromadząc zbiory dla Biblioteki KUL, korzystał z licznych darów książek i czasopism od osób prywatnych, jak również od instytucji. W ramach współpracy bibliotek, około roku 1956 dyrektor podjął ważną decyzję, przekazując Bibliotece Narodowej w Warszawie, bardzo zniszczonej podczas II wojny światowej, część zasobu czasopism i gazet dużego formatu, które Biblioteka KUL otrzymywała $\mathrm{w}$ okresie międzywojennym $\mathrm{w}$ ramach egzemplarza obowiązkowego, a które tematycznie odbiegały od profilu zbiorów gromadzonych przez Bibliotekę. Dodatkowo nie było na KUL odpowiedniego miejsca na zabezpieczenie i dalsze przechowywanie tych zbiorów. Była to prasa nieopracowana przez bibliotekę, ale zabezpieczona w dużych teczkach z grubej tektury, złożona na cementowej posadzce w górnej części sali tzw. kinoteatru. Dar ten odbierał pracownik Biblioteki Narodowej, kustosz Stanisław Piotr Koczorowski, który przyjechał do Lublina samochodem ciężarowym. Uczestniczyłem też w tych niełatwych fizycznych pracach.

Dyrektor, gromadząc książki i czasopisma, które były trudno dostępne w kraju, utworzył i rozbudował Oddział Wymiany Zagranicznej. Poprzez ten oddział Biblioteka KUL otrzymała dużo cennych czasopism i książek naukowych, przede wszystkim zachodnich. Troszczył się, by wszystkie czytelnie były wyposażone w dobre księgozbiory o charakterze uniwersalnym i specjalistycznym, tworząc tzw. księgozbiory prezencyjne. Rozbudował introligatornię, zatrudnił wykwalifikowany personel, zakupił potrzebny sprzęt oraz dbał o konserwację zbiorów.

O. Gustaw z uwagą śledził przebieg obrad Soboru Watykańskiego II i przemian posoborowych. Rozpoczął też gromadzenie licznych publikacji poświęconych tej problematyce, tworząc specjalny księgozbiór posoborowy, który z innymi książkami z dziedziny teologii i religioznawstwa został wykorzystany do utworzenia Czytelni Teologicznej. Dyrektor o. Gustaw przez dłuższy okres opiekował się kaplicą w domu profesorskim, z której również mogli korzystać pracownicy biblioteki. Dzięki jego staraniom został wykonany ołtarz posoborowy.

Obok troski o książkę dyrektor przywiązywał dużą wagę do lokalu dla potrzeb biblioteki. Budynek, w którym obecnie mieści się Biblioteka KUL, przy ul. Chopina 27, został zbudowany przez diecezję lubelską i Akcję Katolicką w stanie surowym w latach 1937-1939, jako Dom Akcji Katolickiej, według projektu arch. inż. Jerzego Siennickiego.

Wybuch II wojny światowej, okres okupacji i sytuacja polityczna w Polsce po 1944 roku zniweczyły te plany. W roku 1947, na prośbę rektora KUL ks. Antoniego Słomkowskiego, budynek ten został przekazany przez bpa Stefana Wyszyńskiego, ówczesnego ordynariusza diecezji, dla uniwersytetu - z przeznaczeniem, po przystosowaniu i jak najszybszej przebudowie części budynku, dla potrzeb biblioteki.

Dzięki staraniom i bardzo dużym zaangażowaniu rektora ks. Antoniego Słomkowskiego oraz ówczesnego dyrektora Biblioteki KUL prof. Andrzeja Wojtkow- 
skiego, w latach 1947-1950 zostały wykonane ważne prace budowlano-adaptacyjne w części gmachu, od strony południowo-wschodniej, według planów opracowanych przez inż. arch. Ignacego Kędzierskiego, uwzględniających, w miarę możliwości technicznych, potrzeby biblioteki. Uroczyste otwarcie i poświęcenie biblioteki w nowym gmachu przy ul. Chopina 27 zostało dokonane w dniu Inauguracji Roku Akademickiego 6 listopada 1949 roku przez prymasa ks. Stefana Wyszyńskiego - przyjaciela i dobroczyńcę KUL. Było to formalne zakończenie pierwszego etapu przebudowy Domu Akcji Katolickiej, dla nowej Biblioteki KUL, przy ul. Chopina 27.

W drugiej połowie 1950 roku Senat KUL powierzył funkcję dyrektora Biblioteki KUL bernardynowi, o. dr. Romualdowi Gustawowi OFM, który w krótkim czasie rozpoznał główne zadania i potrzeby biblioteki. W realizacji trudnych zadań, które stały przed nowym dyrektorem, przez wiele lat uczestniczyli aktywnie dwaj wicedyrektorzy: dr Witold Nowodworski i kustosz Jan Wiśliński oraz dobry, zintegrowany zespół pracowników.

Intensywny rozwój Biblioteki KUL po roku 1950, stwarzał konieczność poszerzenia przestrzeni lokalowej. Mogło to być zrealizowane przez wykorzystanie sali widowiskowej Domu Akcji Katolickiej, tzw. kinoteatru, która była ulokowana w bezpośrednim sąsiedztwie części już używanej i zagospodarowanej. O. Gustaw widział tę wielką potrzebę, ale postawa władz państwowych, bardzo wroga wobec Kościoła i KUL, jak również sytuacja ekonomiczna Uniwersytetu były zbyt trudne, by prace adaptacyjne mogły być wówczas podjęte. Tą częścią budynku, to jest salą widowiskową z pomieszczeniami jej towarzyszącymi, były zainteresowane władze miasta Lublina, z zamiarem umieszczenia tam instytucji kulturalnych (m.in. teatru muzycznego). Tylko dzięki zdecydowanej postawie o. Gustawa, przeciwstawiającego się w sposób stanowczy przekazaniu wymienionej sali dla miasta, zawdzięczać trzeba to, że w najbliższych latach istniała możliwość opracowania planów związanych z pełną adaptacją całego gmachu dla potrzeb Biblioteki Uniwersyteckiej KUL. Władze KUL nie bardzo spieszyły z podjęciem trudnej decyzji o dalszej przebudowie, bowiem na skutek przemian politycznych w Polsce po roku 1956, miano wielkie nadzieje, że będzie można uzyskać pozwolenie na rozbudowę uniwersytetu, w tym również wybudowanie wielkiej, nowoczesnej biblioteki uniwersyteckiej.

W kwietniu 1958 roku SARP (Stowarzyszenie Architektów Rzeczypospolitej Polskiej) ogłosiło ogólnopolski konkurs na rozbudowę KUL. Nagrodzone prace architektoniczne były eksponowane na wystawie jubileuszowej 40-lecia KUL, w październiku 1958 roku. Niestety z tych projektów uniwersytet nic nie mógł zrealizować. Opracowany w ramach konkursu przez architekta Witolda Benedeka (I nagroda) projekt nowej Biblioteki KUL o kubaturze ok. $53.000 \mathrm{~m}^{3}$ na ok. 1.500 .000 książek, nie mógł być też zrealizowany w ówczesnej rzeczywistości politycznej w Polsce. Władze miasta zdecydowały, by na tym terenie został wybudowany Hotel „Unia”.

Dyrektor był realistą i intensywnie zabiegał, by nie rezygnować z planów adaptacji całego gmachu przy ul. Chopina dla potrzeb Biblioteki KUL. W związku z tym władze uniwersytetu zleciły mgr inż. architektowi Tadeuszowi Witkowskie- 
mu opracowanie założeń projektowych do budowy nowej biblioteki obok gmachu KUL, w związku z ogłoszeniem wspomnianego konkursu, jak również wykonanie ogólnego projektu pełnej przebudowy gmachu przy ul. Chopina 27 dla potrzeb Biblioteki KUL.

Architekt T. Witkowski, realizując prośbę KUL, w roku 1958 przedstawił założenia projektowe do budowy nowego gmachu Biblioteki KUL przy Uniwersytecie, Al. Racławickie 14. Opracował równocześnie Projekt techniczny adaptacji budynku przy ul. Chopina 27 dla potrzeb czasowych Biblioteki, który został zatwierdzony w końcu tegoż roku przez Prezydium Miejskiej Rady Narodowej w Lublinie oraz władze uniwersytetu.

W latach 1959-1960 tenże architekt opracował projekt szczegółowy adaptacji - zużytkowania w pełni surowego stanu budynku (z warunkowym wykorzystaniem sali widowiskowej) oraz nadbudowy jednego piętra od strony południowej, nad częścią niższą gmachu, już użytkowaną przez bibliotekę, przylegającą do wymienionej sali, rozpoczynając drugi etap jego przebudowy. W latach 19601963 nadbudowano jedno piętro nad dotychczasową Czytelnią Główną, w części gmachu od strony południowej, uzyskując dużą salę oraz mieszkanie służbowe dla dyrektora biblioteki, o łącznej powierzchni około $200 \mathrm{~m}^{2}$. Rozpoczęto też prace budowlane w dużej sali kinoteatru, którym towarzyszyło w ich trakcie, wiele trudności o charakterze formalnym i konstrukcyjno-budowlanym, jak również związanych ze zdobyciem potrzebnych materiałów, przede wszystkim stali konstrukcyjnej.

Ponadto, książki, czasopisma, dublety oraz zbiory depozytowe nieopracowane, liczące kilkadziesiąt tysięcy woluminów, które z braku miejsca nie mogły być przechowywane w pomieszczeniach formalnie przeznaczonych dla biblioteki, składowane były w części sali kinoteatru, gdzie rozpoczynano prace budowlane. Zostały one przewiezione w roku 1962 do nowego głównego magazynu gospodarczego na Poczekajce, gdzie władze uniwersyteckie przydzieliły Bibliotece KUL, jedno piętro o powierzchni ok. $500 \mathrm{~m}^{2}$. Chociaż było ono nieprzystosowane dla potrzeb biblioteki, bez odpowiedniego oświetlenia elektrycznego, ogrzewania, wody, a przede wszystkim bez regałów na książki, o. Gustaw polecił nam, by książki były układane na podłodze $\mathrm{z}$ użyciem podkładów z desek, a następnie ustawiane na regałach drewnianych uzyskanych z magazynów Biblioteki KUL przy ul. Chopina 27, gdzie trwała wymiana regałów na metalowe. Zbiory te w późniejszym okresie były sukcesywnie porządkowane, opracowywane i selekcjonowane. Magazyn ten, chociaż nie był wyposażony w potrzebne instalacje techniczne, służył Bibliotece KUL przez około 25 lat, tj. do czasu ukończenia nowego sześciokondygnacyjnego magazynu poligraficzno-bibliotecznego na Poczekajce, gdzie na trzech piętrach o powierzchni ok. $1500 \mathrm{~m}^{2}$ został urządzony nowoczesny magazyn aneksowy dla potrzeb Biblioteki KUL, dzięki staraniom dyrektora Andrzeja Paluchowskiego.

Na skutek powstałych utrudnień, zaistniała potrzeba częściowej, istotnej zmiany dotychczasowego projektu. Architekt T. Witkowski nie podjął się tego zadania i niedługo zrezygnował z dalszej współpracy z KUL, gdyż był zaangażowany 
w opracowanie projektu nowej Biblioteki UMCS, który został zrealizowany w latach 1963-1968 według jego planów.

W związku z tym w roku 1963 został zatrudniony w KUL mgr inż. architekt Zbigniew Zawora. Architekt ten, po przeanalizowaniu całej koncepcji architektonicznej przebudowy gmachu biblioteki, opracowanej przez arch. T. Witkowskiego, oraz uwzględniając już wykonane liczne prace budowlane i istniejące trudności, sporządził pełną inwentaryzację budynku. Z powodu konieczności wprowadzenia zmian w dotychczasowej dokumentacji, architekt Zawora opracował nowy Projekt (adaptacja) techniczno-roboczy Biblioteki Uniwersyteckiej KUL, Chopina 27.

Zgodnie z tym projektem została wyburzona niemal cała konstrukcja, wybudowanej przed rokiem 1939 w stanie surowym, sali widowiskowej - kinoteatru oraz zlikwidowano dwie klatki schodowe od strony ul. Chopina. Zmniejszono wysokość wcześniej zaprojektowanej przez arch. Tadeusza Witkowskiego, sali Czytelni Głównej na IV piętrze. Uzyskano przestrzeń na wybudowanie dodatkowego szóstego magazynu bibliotecznego. Urządzono nowe wejście do biblioteki oraz duży hall, szatnię i pomieszczenie na wypożyczalnię. Przebudowano pomieszczenie na parterze od strony południowej, obok sali kinoteatru, gdzie dotychczas mieścił się depozytowy księgozbiór Ojców Jezuitów - Bobolanum, który został przewieziony do Warszawy, oraz introligatornia biblioteki. W tej części gmachu ulokowano Czytelnię Czasopism.

Po zatwierdzeniu tego projektu przez rektora ks. Wincentego Granata i Senat Akademicki KUL, dalsza przebudowa była kontynuowana według koncepcji architekta Z. Zawory z częściowym uwzględnieniem korekty proponowanej przez Bibliotekę KUL.

Z końcem 1966 roku został zatrudniony w KUL mgr inż. architekt Antoni Herman, w celu zaprojektowania wnętrza Czytelni Głównej, pomieszczeń z nią sąsiadujących, klatki schodowej, hallu na parterze z szatnią i Wypożyczalnią Książek. Przedstawił również propozycję uporządkowania otoczenia gmachu Biblioteki KUL, od strony ul. Chopina.

W zaistniałej sytuacji, do czuwania nad przebiegiem prac związanych z przebudową, dyrekcja biblioteki powołała w 1962 r. komisję wewnętrzną, z wicedyrektorem Janem Wiślińskim, której zostałem też członkiem. Komisja ta została w roku 1965 przekształcona i działała przez dłuższy okres jako podkomisja Senackiej Komisji Bibliotecznej. Zadaniem jej była kontrola prac i opiniowanie wszelkich projektów mających związek z przebudową, z punktu widzenia użytkownika gmachu. Wysunięte przez komisję oraz o. Gustawa propozycje zmian w projekcie opracowanym przez inż. architekta Z. Zaworę, w miarę możliwości zostały uwzględnione i zatwierdzone przez rektora ks. W. Granata i Senat Akademicki KUL.

Władze Uniwersyteckie uznały za potrzebne zawarcie umowy o współpracy, związanej z przebudową gmachu, z wicedyrektorem J. Wiślińskim oraz kustoszem $F$. Chwalewskim. $Z$ proponowanego nam honorarium zrezygnowaliśmy, traktując nasze zaangażowanie w przebudowę gmachu jako pracę dla dobra Biblioteki i KUL. 
W czasie trwania trudnych prac adaptacyjno-budowlanych w Bibliotece KUL, byli zatrudnieni znani lubelscy architekci: Tadeusz Witkowski, Zbigniew Zawora oraz Antoni Herman. Projekty wszystkich wnętrz Czytelni Głównej, Czasopism, Profesorskiej i Informacji Naukowej, Zbiorów Specjalnych, Starych Druków oraz hallów, regałów, gablot wystawowych wykonali architekci: Juliusz Kłeczek oraz Antoni Herman. Projekty instalacji wodnych, sanitarnych i ciepłowniczych wykonał inż. dr Janusz Kwiatkowski, instalacji elektrycznych inż. Jan Dwornicki oraz inż. Henryk Szacoń. Nadzór nad pracami budowlanymi pełnili technik budowlany Albin Wargocki oraz mgr inż. Lucjan Waszczuk.

Należy podkreślić, że projekty konstrukcyjne oraz obliczenia wytrzymałościowe w całym gmachu przy ulicy Chopina 27, od rozpoczęcia jego budowy, to jest od 1937 roku, łącznie z wszystkimi obliczeniami konstrukcyjnymi związanymi z przebudową gmachu w pierwszym i drugim etapie przebudowy, aż do roku 1971, wykonał znany inżynier konstruktor Henryk Zamorowski.

Niemal przez cały okres przebudowy gmachu, duży wpływ na jego przebieg miał ks. dr Franciszek Woronowski, dyrektor administracyjny KUL.

Dyrektor o. Gustaw był bardzo zaangażowany przez cały czas prac związanych z przebudową biblioteki, martwiąc się ich powolnym przebiegiem. Prace te były prowadzone przez dział remontowo-budowlany KUL, systemem gospodarczym. Po kilku latach ogrom prac przyniósł widoczne efekty. Uzyskano duże przestrzenie magazynowe i miejsca na urządzenie nowych pięciu specjalistycznych czytelni, natomiast $\mathrm{w}$ minimalnym stopniu poprawiły się warunki pracy w biurach bibliotecznych.

Ważnym wydarzeniem było otwarcie w dniu 17 kwietnia 1972 roku nowej Czytelni Głównej na czwartym piętrze, której wnętrze zaprojektował inż. architekt Antoni Herman. Do jej utworzenia wykorzystano przestrzeń nad nowo wybudowanymi sześcioma kondygnacjami magazynów na książki. Duża powierzchnia sali $\left(\right.$ ok. $420 \mathrm{~m}^{2}$ ) umożliwiła utworzenie miejsc dla 160 czytelników (w starej czytelni było 96 miejsc). Na regałach przyściennych można było ulokować księgozbiór podręczny liczący około 15.000 woluminów (w starej czytelni było ok. 9.000 woluminów). Wyposażono czytelnię w nowe regały wykonane w drewnie oraz stoły z możliwością korzystania z lamp elektrycznych. Przy jednej ścianie wybudowano antresolę z regałami, by powiększyć księgozbiór i uzyskać dodatkowe miejsca dla czytelników. Zaprojektowano sygnalizację świetlną przywołującą czytelników oraz wentylację mechaniczną. Wykonano również podium dla pracowników obsługi, w sąsiedztwie windy dostarczającej bezpośrednio zamówione książki z magazynów. Jako wieloletni kierownik Czytelni Głównej byłem zaangażowany w staranne jej wykończenie według projektów architektonicznych inż. A. Hermana oraz projektów instalacji elektrycznych inż. H. Szaconia.

Dyrektor o. Gustaw był szczególnie zainteresowany budową i wyposażeniem Czytelni Głównej. Często mówił, że powinna być ona wizytówką biblioteki. Przez wiele lat jej funkcjonowania, często były zajęte wszystkie miejsca.

W roku 2008 w Czytelni Głównej przeprowadzono prace remontowe, ponieważ w latach 1998-2009 władze KUL oraz dyrektor Biblioteki KUL ks. dr Tadeusz Stolz, po odzyskaniu zawłaszczonej przez władze miasta części działki 
uniwersyteckiej przy ul. Chmielarczyka o powierzchni ok. $100 \mathrm{~m}^{2}$ dobudowały do istniejącego gmachu biblioteki, nową bryłę budynku o kubaturze około $10000 \mathrm{~m}^{3}$ według projektu arch. Jerzego Grochulskiego.

W staraniach o odzyskanie tej działki brałem czynny udział. W nowej części budynku zostały utworzone magazyny, wypożyczalnia, pomieszczenia dyrekcji, pracownie biblioteczne oraz nowa Czytelnia Teologiczno-Filozoficzna na IV piętrze, w bezpośrednim sąsiedztwie Czytelni Głównej. Projektant wnętrza nowej czytelni mgr inż. arch. Małgorzta Wałęga oraz dyrektor Biblioteki KUL ks. T. Stolz zdecydowali, że należy wprowadzić liczne zmiany w istniejącej Czytelni Głównej, zmieniając jej architektoniczną odrębność.

W 1971 roku nastapiło formalne zakończenie przebudowy budynku dla potrzeb biblioteki o łącznej kubaturze ponad $26.000 \mathrm{~m}^{3}$. Przedstawiony został dokument kolaudacyjny sporządzony przez inżynierów projektantów i władze administracyjne KUL. Dyrektor, chociaż cieszył się z tego faktu, słusznie uważał, że do ostatecznego ukończenia przebudowy gmachu pozostaje jeszcze podział starej czytelni głównej na dwa poziomy i wybudowanie na jednym $\mathrm{z}$ nich pomieszczeń biurowych dla pracowników oraz urządzenie na poziomie pierwszego piętra podzielonej sali, pomieszczenia na czytelnię profesorską i informacji naukowej. Władze KUL uważały, że jest to niemożliwe do wykonania z powodów finansowych i braku ekipy budowlanej na uniwersytecie oraz że stara czytelnia, bez przebudowy powinna pozostać dla potrzeb ogólnouniwersyteckich.

Dyrektor o. Gustaw uważał jednak, że należy, zgodnie z projektem, dokonać podziału tej sali, gdyż brakowało pomieszczeń biurowych dla pracowników bibliotecznych. Z powodu odmowy wykonania dalszych prac adaptacyjnych w gmachu biblioteki przez KUL, o. Gustaw prosił władze uczelni o uwzględnienie ważnych potrzeb lokalowych oraz kontynuowanie robót budowlanych. Postulat ten poparła Senacka Komisja Biblioteczna, zwołana w tej sprawie na prośbę dyrektora. Po kilku dalszych rozmowach z rektorem o. A. Krąpcem, dyrektor zdecydował, by prace budowlane były kontynuowane przez bibliotekę bez pomocy ekip uniwersyteckich. Zapewnił, że koszty tych prac będą pokryte z funduszy uzyskanych przez uczelnię ze sprzedaży bibliotecznych książek dubletowych, w antykwariatach w Bydgoszczy i Krakowie. W związku z tym planem o. Gustaw zwrócił się do mnie o pomoc w wyszukaniu odpowiedniej firmy remontowo-budowlanej w Lublinie, która wykonałaby zaplanowane prace. Wicedyrektor Biblioteki kustosz J. Wiśliński, który miał doświadczenie w sprawach techniczno-budowlanych, był już na emeryturze. Szczęśliwie się złożyło, że znałem mojego starszego kolegę z okresu studiów na KUL - mgr Adolfa Szaryka, który był prezesem Spółdzielni Pracy Remontowo-Budowlanej w Lublinie. Zwróciłem się do niego $\mathrm{z}$ prośbą pomoc $\mathrm{w}$ realizacji prac budowlanych $\mathrm{w}$ bibliotece. Radził mi, aby Biblioteka nawiązała kontakt i współpracę ze Stefanem Kaisem, który kierował grupą budowlano-montażową tej spółdzielni. S. Kais po zapoznaniu się z zakresem koniecznych robót budowlanych wyraził zgodę na wykonanie prac tylko budowlano-konstrukcyjnych, bez robót wykończeniowych (elektrycznych, hydraulicznych, ciepłowniczych, stolarskich, malarskich oraz ułożenia parkietu). 
Po przeanalizowaniu tej propozycji, o. Gustaw prosił, by została zawarta umowa między Spółdzielnią a KUL na wykonanie prac budowlano-konstrukcyjnych bez prac wykończeniowych. Treść umowy i kosztorys zostały sprawdzone i skorygowane przez rzeczoznawców budowlanych. Obliczenia konstrukcyjne wykonali inżynierowie zatrudnieni na KUL. Ażeby całość prac mogła być zrealizowana, dyrektor prosił mnie o dalszą pomoc i udział w staraniach o znalezienie odpowiednich wykonawców prac wykończeniowych. Znając wielu dobrych rzemieślników pracujących na KUL w różnych branżach budowlanych, zwróciłem się do nich z prośbą, by podjęli się wykonania prac specjalistycznych w bibliotece poza godzinami służbowymi, w ramach umów o prace zlecone. Chętnie wyrazili na to zgodę. Dyrektor aprobował te propozycje i ustalenia oraz zlecił mi nadzór i koordynację tych prac. Te skomplikowane, czasochłonne i trudne dla mnie sprawy związane z przebudową byłej czytelni zakończyły się dobrze, a z pomieszczeń uzyskanych w wyniku przebudowy, trwającej nieco ponad rok, biblioteka korzysta do dzisiaj. Łączne koszty tych prac były bardzo korzystne dla uniwersytetu. W sali uzyskanej po przebudowie na pierwszym piętrze utworzono Czytelnię Profesorską (równocześnie: Informacji Naukowej), gdzie przez kilkanaście lat odbywały się także liczne konferencje i sympozja naukowe. W dniach 21-22 maja 1976 roku w tej Czytelni odbyły się obrady Międzynarodowej Federacji Uniwersytetów Katolickich (FIUC), w których brał udział i wygłosił wykład ks. kard. Karol Wojtyła. Na drugim piętrze zlokalizowano pracownie biblioteczne.

Należy również przypomnieć, że z inicjatywy o. Gustawa szereg prac związanych z wykończeniem i wyposażeniem wnętrz czytelni specjalistycznych, zostało zrealizowanych przez bibliotekę również we własnym zakresie, z funduszy uzyskanych ze sprzedaży książek dubletowych w antykwariatach.

Dyrektor był znany w Polsce jako bibliotekoznawca i naukowiec szczególnie zainteresowany religioznawstwem i teologią. Brał udział w redagowaniu książek: Religie świata, Podręczna encyklopedia biblijna, t. 1-2, Hagiografia Polska, t. 1-2 oraz był współtwórcą pracy zbiorowej pt. Biblioteka Uniwersytecka KUL 19181970, zamieszczonej w czasopiśmie „Archiwa Biblioteki i Muzea Kościelne”, 23 (1971), i innych opracowań. Współpracował z redakcją Encyklopedii katolickiej i starał się o to, by redakcja ta była zlokalizowana w gmachu Biblioteki KUL. Gdy okazało się, że początkowo przydzielony lokal w tak zwanej kinooperatorowni (cztery małe pracownie) nie pozwalał na zwiększenie zespołu pracowników redakcyjnych, o. Gustaw zdecydował odstąpić dodatkowe pomieszczenie, wycofując $\mathrm{z}$ dwóch kondygnacji magazynowych (magazynów starych) księgozbiór liczący kilkanaście tysięcy woluminów. W trakcie prowadzonych tam prac remontowych nastąpiła awaria sieci ciepłowniczej, która spowodowała pewne szkody w zbiorach bibliotecznych.

Dyrektor był jedynym gospodarzem w budynku biblioteki, korzystał bowiem z nowego mieszkania służbowego na trzecim piętrze w części nadbudowanej, od strony podwórza. Wspomniana awaria była dla niego bardzo przykrym przeżyciem. Była to niedziela 17 października 1971 roku, dzień beatyfikacji o. Maksymiliana Kolbe w Rzymie. Czasami wspominał, że jest nie tylko zakonnikiem-pustelnikiem, ale także gospodarzem-stróżem, gdyż w bibliotece od lat 
nie było żadnego portiera i nocnego dozoru. Były też wielkie trudności z łącznością telefoniczną dyrektora $\mathrm{z}$ mieszkańcami domu profesorskiego w sąsiedztwie. $\mathrm{W}$ tej sytuacji przez pewien czas, do komunikacji między mieszkaniem, a domem profesorskim korzystano z aparatów telefonicznych korbkowych tzw. polowych, które były zakupione z demobilu wojskowego.

Dyrektor o. Gustaw organizował dla pracowników Biblioteki KUL kursy dokształcające i wykłady, które były wygłaszane przez znanych bibliotekarzy i bibliotekoznawców z różnych ośrodków naukowych w Polsce. Umożliwiał również pracownikom biblioteki udział w szkoleniach i seminariach w innych ośrodkach bibliotekarskich w Polsce. Za zgodą dyrektora uczestniczyłem trzykrotnie w dwutygodniowych wakacyjnych ogólnopolskich seminariach bibliotekarskich w Jarocinie oraz Gdańsku-Sopocie, które były organizowane przez Stowarzyszenie Bibliotekarzy Polskich dla pracowników bibliotek naukowych w Polsce. Wspominam o tym tylko dlatego, ponieważ poza interesującymi wykładami połączonymi z dyskusją, usłyszałem wiele pozytywnych opinii na temat Biblioteki KUL i jej dyrektora.

O. R. Gustaw był inicjatorem i uczestnikiem kilku ciekawych wycieczek naukowo-poznawczych, zorganizowanych dla pracowników Biblioteki KUL, m.in. do Krakowa i Kalwarii Zebrzydowskiej, wycieczki w rejon Bieszczad z trasą przez Leżajsk (z klasztorem bernardynów), Przemyśl, Duklę (miejscowość znana z kultu św. Jana z Dukli) oraz Miejsce Piastowe (z grobem bł. ks. Bronisława Markiewicza - założyciela Zgromadzenia Księży Michalitów). Podczas tych wycieczek o. R. Gustaw angażował się jako kompetentny przewodnik.

Po otwarciu Czytelni Głównej i jej zradiofonizowaniu powstały korzystne warunki, by organizować w Bibliotece KUL spotkania i odczyty z wybitnymi bibliotekarzami i bibliotekoznawcami, zapraszając do uczestnictwa w nich również pracowników bibliotek naukowych miasta Lublina. W latach 1973-1975 dyrektor o. Gustaw i wicedyrektor Andrzej Paluchowski zorganizowali około dziesięciu wykładów znanych bibliotekarzy, bibliofilów i edytorów m.in. profesorów: Jana Baumgarta, Marii Dembowskiej, Karola Estreichera (wnuka), Juliusza Wiktora Gomulickiego i Alodii Gryczowej. Wiele z tych wykładów miałem przyjemność wysłuchać i nagrać na taśmy magnetofonowe, by zachować je w zbiorach archiwalnych biblioteki.

Po kilku latach intensywnej pracy jako dyrektor Biblioteki KUL o. Gustaw podjął starania, by przy bibliotece został utworzony centralny ośrodek, który by koordynował i wspomagał działalność bibliotek kościelnych w całej Polsce. Realizacja tych planów była trudna. Po kilku latach starań, dzięki poparciu tej inicjatywy przez Episkopat Polski i władze KUL, w roku 1956 został utworzony Ośrodek Archiwów Bibliotek i Muzeów Kościelnych, który również rozpoczął w 1959 roku wydawanie czasopisma naukowego. Było to ważne wydarzenie w życiu i działalności Kościoła w Polsce. Przed oficjalnym powstaniem Ośrodka ABMK, o. Gustaw zorganizował dwa kursy szkoleniowe dla księży i zakonników pracujących w bibliotekach kościelnych, w których - w miarę możliwości i potrzeby - mogłem uczestniczyć jako pracownik Czytelni Głównej, gdzie odbywały się te wykłady. Wygłaszali je o. Gustaw oraz znani w Polsce bibliotekarze 
i bibliotekoznawcy. W roku 1959 Władze Uniwersyteckie KUL zdecydowały o przekształceniu Ośrodka ABMK w uniwersytecki zakład międzywydziałowy z szerokim programem działalności organizacyjno-naukowej. Współpracuje z nim również Biblioteka KUL.

Wszechstronna działalność o. Gustawa była znana w Polsce i poza jej granicami. W latach siedemdziesiątych dyrektor korzystał z kilku zagranicznych wyjazdów, w celu zapoznania się z organizacją i pracami w bibliotekach uniwersyteckich w Europie. W połowie 1975 roku odbył dłuższą podróż do Stanów Zjednoczonych i Kanady, by odwiedzić liczne ośrodki naukowe, a przede wszystkim biblioteki, z którymi Biblioteka KUL utrzymywała kontakty. Chciał poznać ich bogate ksiegozbiory i organizację pracy $\mathrm{z}$ wykorzystaniem nowoczesnych środków technicznych. Po powrocie z USA na zebraniu pracowników Biblioteki KUL opowiadał o przebiegu podróży i dzielił się swoimi spostrzeżeniami. Podkreślał, że Biblioteka KUL, chociaż ma liczne osiągnięcia, jest opóźniona, jeżeli chodzi o wyposażenie w nowoczesne środki techniczne, które ułatwiałyby pracę bibliotekarzom i czytelnikom, umożliwiając im m.in. wolny dostęp do półek w magazynach bibliotecznych.

Dyrektor miał też inne plany dotyczące rozbudowy biblioteki i magazynów, przede wszystkim utworzenie magazynu aneksowego książek na Poczekajce. Został on wybudowany kilka lat po jego śmierci, jako duży sześciokondygnacyjny gmach dla potrzeb Biblioteki i Poligrafii KUL. Niestety po kilkunastu latach, budynek ten został przystosowany do potrzeb dydaktycznych uczelni, a więc Biblioteka KUL utraciła lokal magazynowy liczący ok. $1.500 \mathrm{~m}^{2}$.

Przygotowywał również program dwuletniego międzywydziałowego kursu bibliotekarskiego oraz, wspólnie z Ośrodkiem ABMK, mniejszych kursów. $\mathrm{W}$ niedługim czasie, po powrocie dyrektora z zagranicy, miała się odbyć w Bibliotece w dniach 15-17 stycznia 1976, planowana już wcześniej, ogólnopolska konferencja naukowa pod tytułem Problemy współczesnej biblioteki naukowej, połączona z uroczystościami jubileuszowymi 25-lecia pracy w Bibliotece KUL o. Gustawa, podczas której planował wygłosić wykład pt. Projekt organizacji wspólpracy bibliotek kościelnych $w$ Polsce.

Niestety plany te nie zostały zrealizowane. O. Gustaw zmarł niespodziewanie w dniu 14 stycznia 1976 roku i zamiast planowanej konferencji i uroczystości jubileuszowych nastały dni żałoby.

Uroczystości pogrzebowe o. R. Gustawa rozpoczęły się mszą św. odprawioną w intencji zmarłego w Kościele Akademickim KUL, z licznym udziałem duchowieństwa, władz uniwersyteckich oraz społeczności akademickiej, jak również mieszkańców Lublina. Następnie kondukt żałobny z trumną wyruszył z kościoła i przeszedł ul. M. Curie-Skłodowskiej na cmentarz przy ul. Lipowej w Lublinie, gdzie był przygotowany grobowiec. Pomimo mroźnej pogody, w pogrzebie uczestniczyło wiele osób. W przeddzień uroczystości pogrzebowych trumna ze zwłokami dyrektora była wystawiona w sali czytelni naukowej na pierwszym piętrze w Bibliotece KUL. W godzinach nocnych przy trumnie trwały czuwania modlitewne z udziałem pracowników biblioteki oraz osób zaprzyjaźnionych ze zmarłym. 
Po obrzędach pogrzebowych i złożeniu trumny do grobowca, pozostała sprawa wykonania płyty nagrobkowej nad kryptą. Ekshumowano również zwłoki matki o. Gustawa - Zofii i złożono do wspólnego grobu. Ustalono, że sprawą związaną z wykonaniem nagrobka zajmie się kierownictwo Biblioteki KUL, z jej nowym dyrektorem Andrzejem Paluchowskim. Realizacja tych prac okazała się trudna, gdyż przeznaczone na ten cel fundusze były skromne, a zakłady usług kamieniarskich w Lublinie nie posiadały płyt granitowych, z których według propozycji architekta Juliusza Kłeczka miał być wykonany nagrobek. Dyrektor biblioteki zwrócił się do mnie z prośbą o pomoc w załatwianiu spraw związanych z wykonaniem nagrobka. Przy wsparciu władz KUL oraz środowiska bibliotekarskiego w Lublinie, prośba o zakup potrzebnej płyty granitowej (po cenach urzędowych) w zakładach kamieniarskich w Strzegomiu na Śląsku została załatwiona pozytywnie. Niestety inż. architekt Juliusz Kłeczek nie mógł uczestniczyć w dalszych pracach, a przede wszystkim wykonać wzorów liter, które były potrzebne przy planowanym odlewie $\mathrm{w}$ brązie. W związku $\mathrm{z}$ tym projekt liter oraz ich planowany układ graficzny wykonali pracownicy Czytelni Głównej Biblioteki KUL, natomiast litery z drewna lipowego potrzebne do odlewu wykonał rzeźbiarz-amator $z$ Lublina - p. Kwiatkowski. Inne potrzebne prace zostały zrealizowane przez Zakład Odlewniczy w Lublinie przy ul. Żabiej oraz Zakład Ślusarski Józefa Bednarczyka, który już wcześniej wykonywał dla biblioteki regały metalowe. Montaż płyty na grobie dyrektora został wykonany przez Zakład Kamieniarski Nowakowskiego. Płyta nagrobna jest skromnym, materialnym znakiem pamięci o życiu, działalności i zasługach o. dr Romualda Gustawa, dyrektora Biblioteki Uniwersyteckiej KUL.

Kończę moje okolicznościowe wspomnienie o o. R. Gustawie współtwórcy nowoczesnej Biblioteki KUL i jej wybitnym i zasłużonym dyrektorze, osobie niepospolitej, cieszącej się wielkim autorytetem w KUL i środowiskach bibliotekarskich świeckich i kościelnych w Polsce.

Dziękuję serdecznie wszystkim organizatorom uroczystości za umożliwienie nam tego spotkania.

Dla nas pracowników Biblioteki KUL, o. Gustaw był wzorem wielkiej pracowitości i kompetencji, szczególnie w zakresie bibliotekarstwa, bibliotekoznawstwa i bibliografii. Był po prostu wzorem miłośnika książki. Od pracowników wymagał zaangażowania w pracy, darzył ich też zaufaniem i życzliwością oraz starał się bardzo, w miarę możliwości materialnych uczelni, o poprawę uposażenia pracowników biblioteki. Posiadał duże zdolności organizatorskie. Cechowała go wielka odwaga w podejmowaniu trudnych decyzji, potrafił pokonywać przeszkody w realizacji planów związanych z potrzebami biblioteki, przede wszystkim lokalowymi. W staraniach o Bibliotekę KUL bywał człowiekiem nieustępliwym. Zasługi Jego dla naszej biblioteki są ogromne i trudno je wyrazić słowami. Biblioteka była bowiem główną troską Jego życia.

Jeszcze przed śmiercią o. Gustawa, rektor KUL o. Albert Krąpiec OP, w wywiadzie prasowym z okazji inauguracji roku akademickiego w roku 1974 powiedział, że od momentu, kiedy dyrektorem Biblioteki KUL został o. doc. dr Romuald Gustaw OFM, stała się ona żywym warsztatem pracy naukowej o dużej służebności społecznej oraz stwierdził: „Mamy najbardziej solidny fundament dla pracy uniwersyteckiej”. 


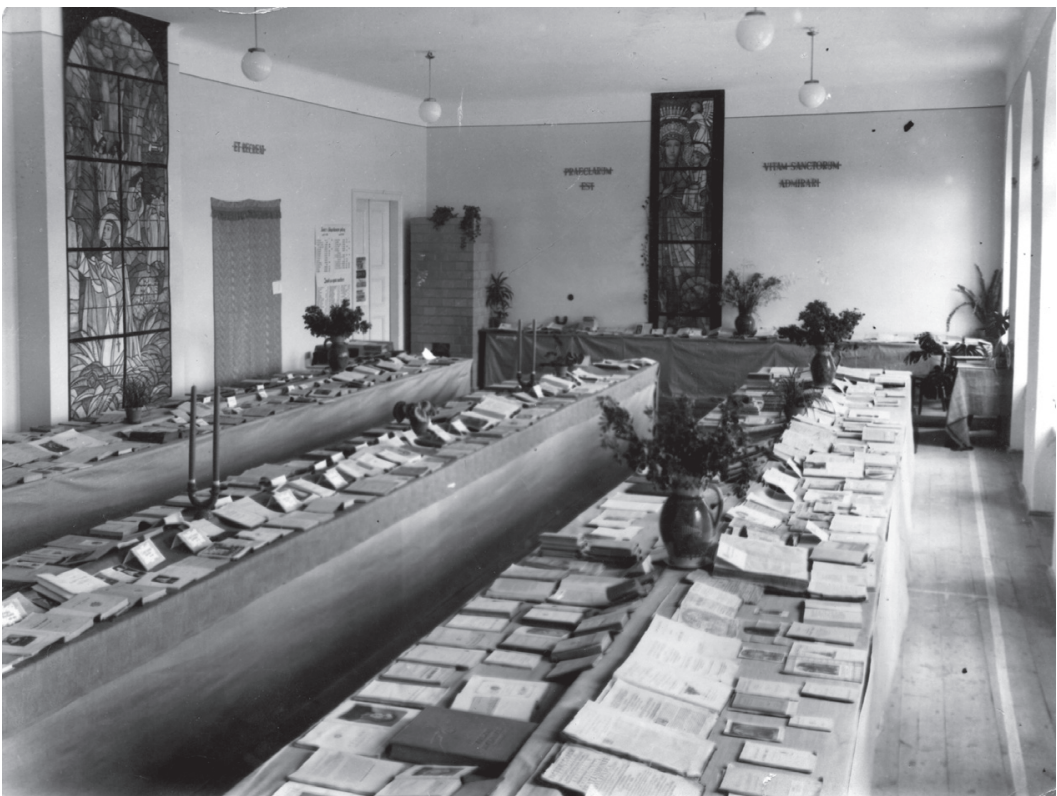

Fot. 1. Wystawa hagiograficzna Święci Polscy w gmachu KUL zorganizowana przez Bibliotekę KUL z okazji wakacyjnych wykładów dla duchowieństwa w 1957 r. Zbiory autora.

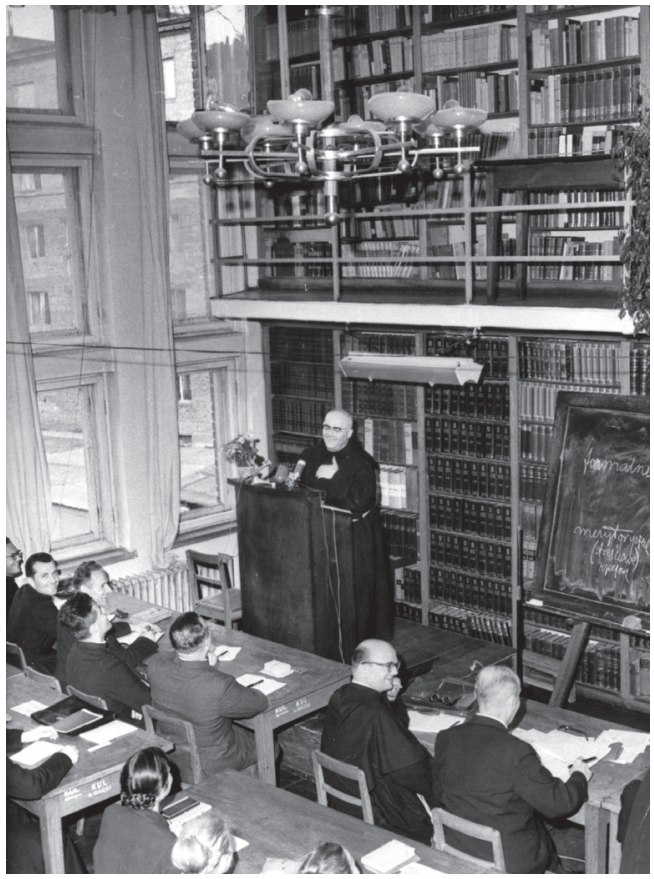

Fot. 2. Wykład dyrektora o. R. Gustawa w ramach kursu dla archiwistów i bibliotekarzy kościelnych zorganizowanego przez Bibliotekę KUL w 1956 r. Zbiory autora. 


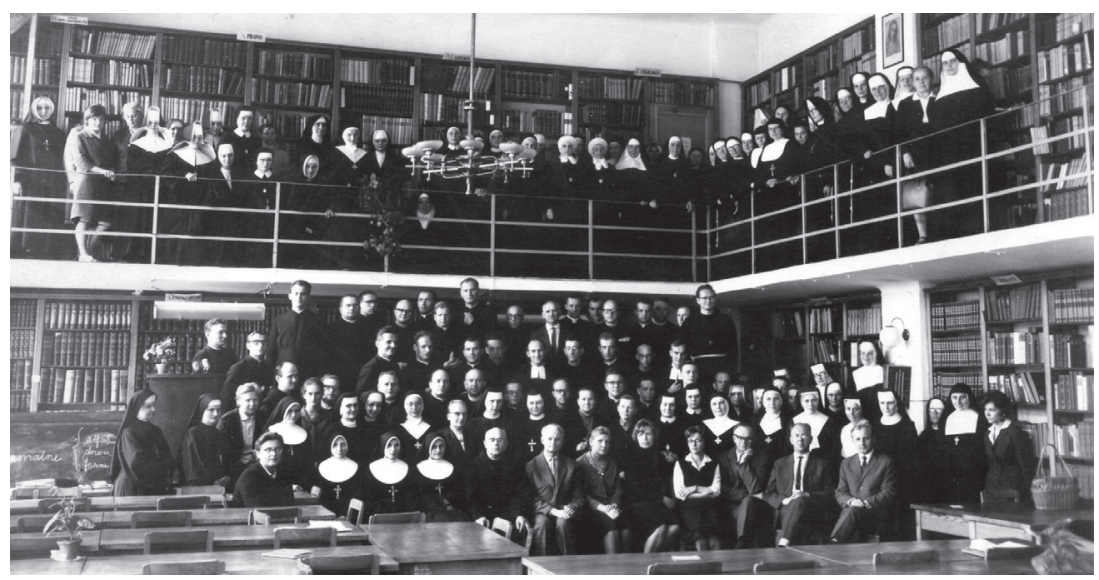

Fot. 3. Uczestnicy kursu zorganizowanego przez Bibliotekę KUL i Ośrodek ABMK dla bibliotekarzy kościelnych w 1960 r. Zbiory autora.

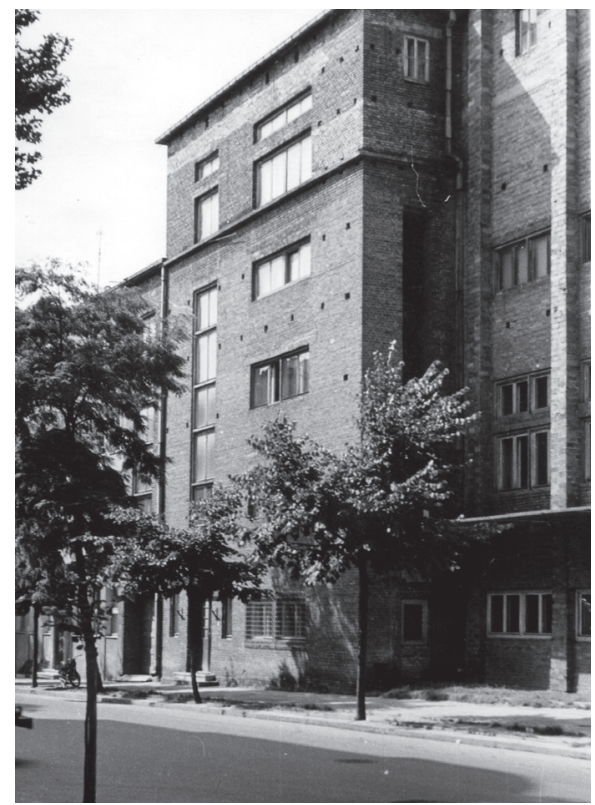

Fot 4.Widok gmachu Biblioteki KUL od strony ul. Chopina, przed przebudową w latach 1960-1971. Zbiory autora. 


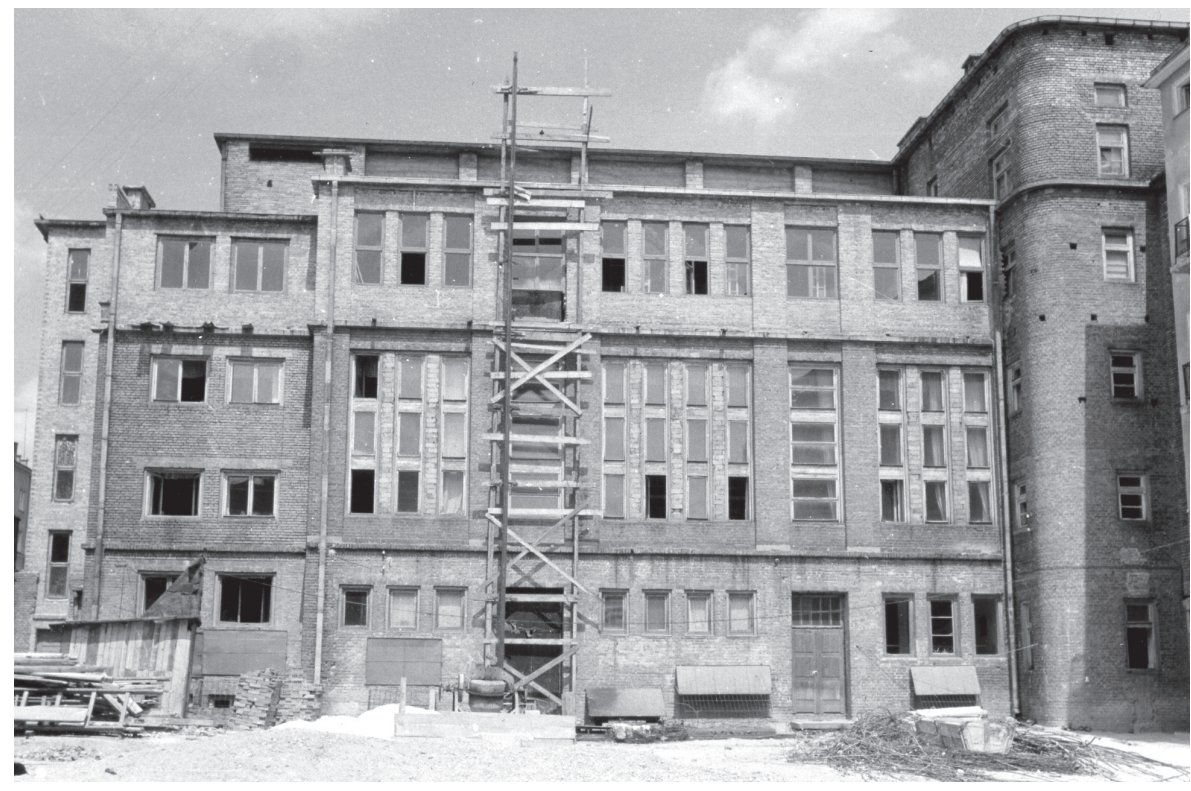

Fot. 5. Widok Biblioteki KUL od strony podwórza, podczas przebudowy w latach 1960-1971. Zbiory autora.

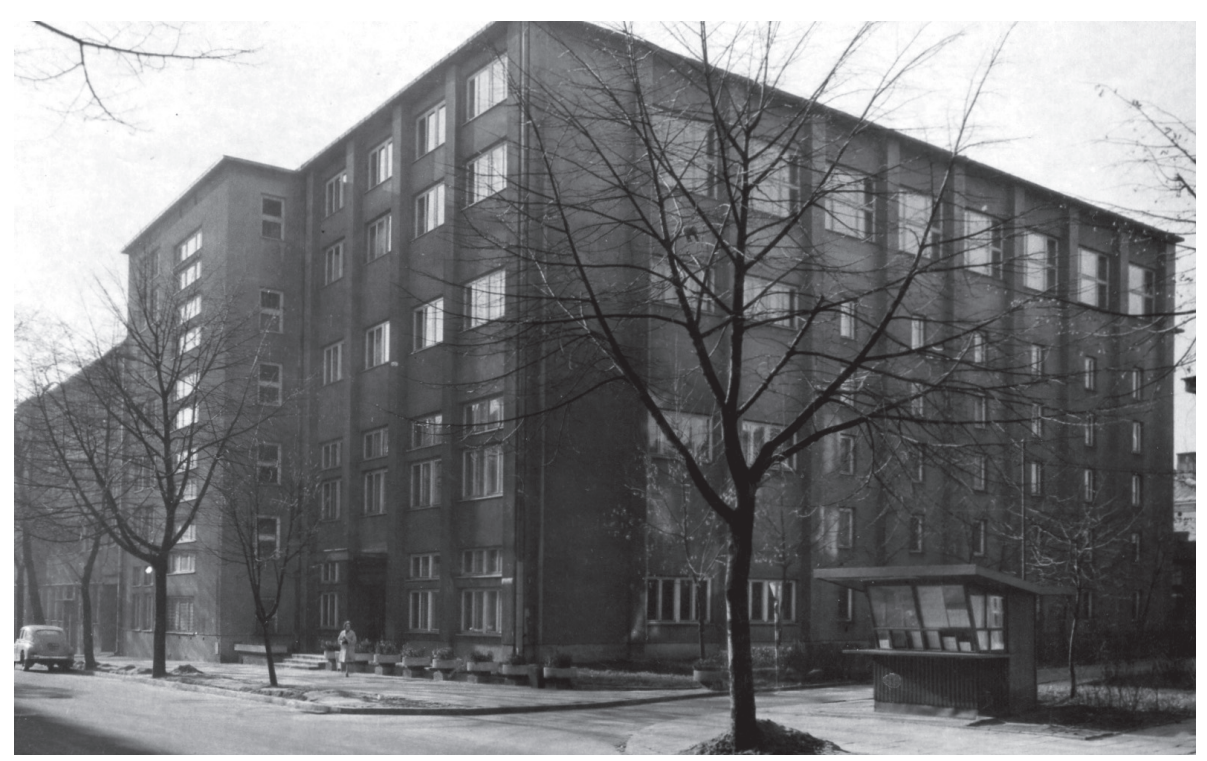

Fot. 6. Biblioteka Uniwersytecka KUL, ul. Chopina 27, w roku 1972, po przebudowie gmachu w latach 1960-1971. Zbiory autora. 


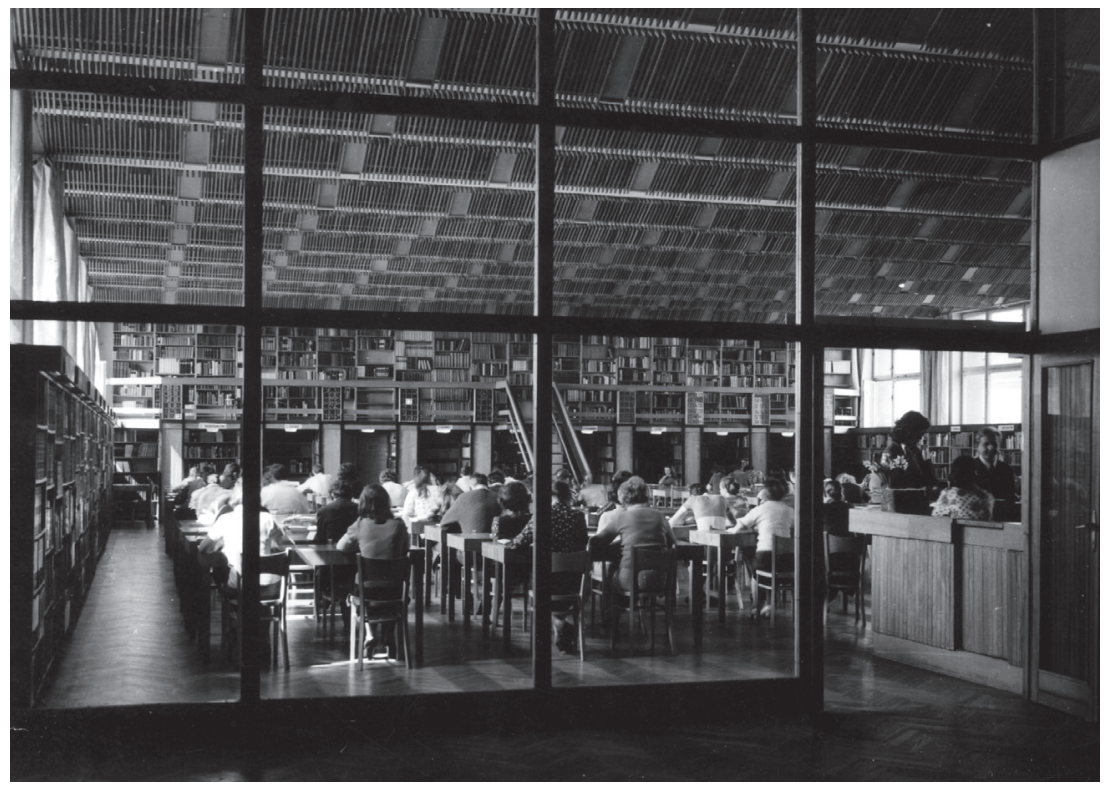

Fot. 7.Nowa Czytelnia Główna na IV piętrze, ok. 1974 r. Zbiory autora.

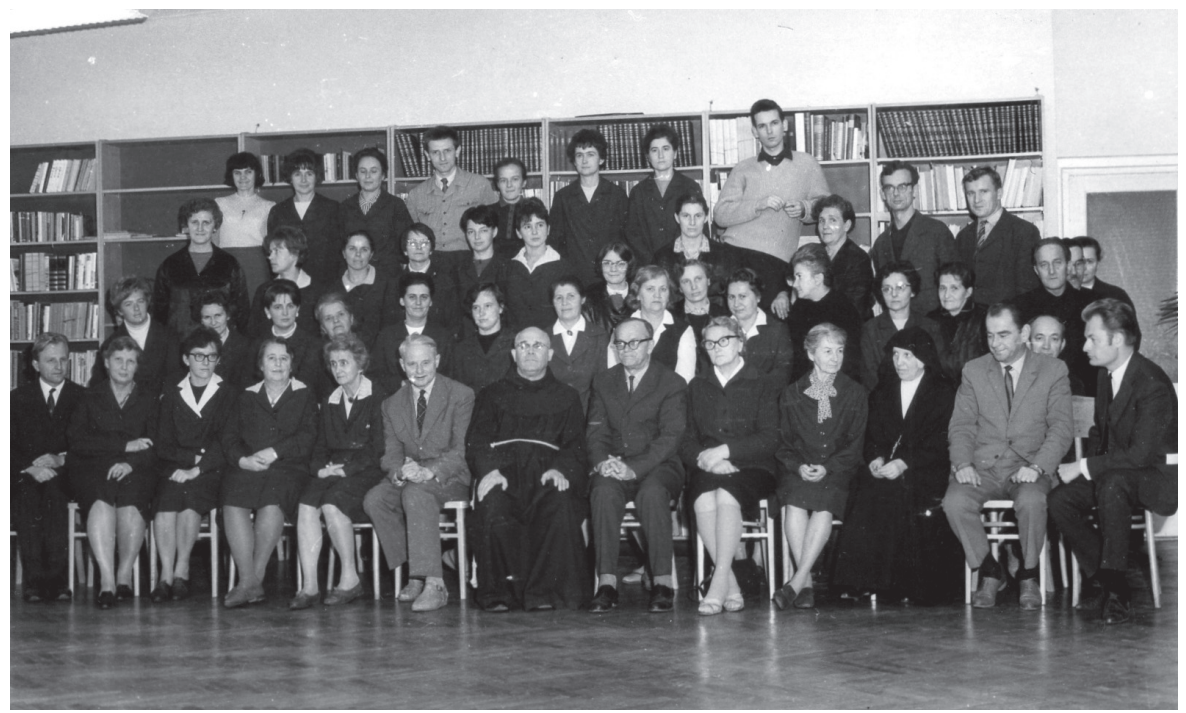

Fot. 8. Pracownicy Biblioteki KUL z dyrekcją w Czytelni Teologicznej na III piętrze w 1970 r. Zbiory autora. 


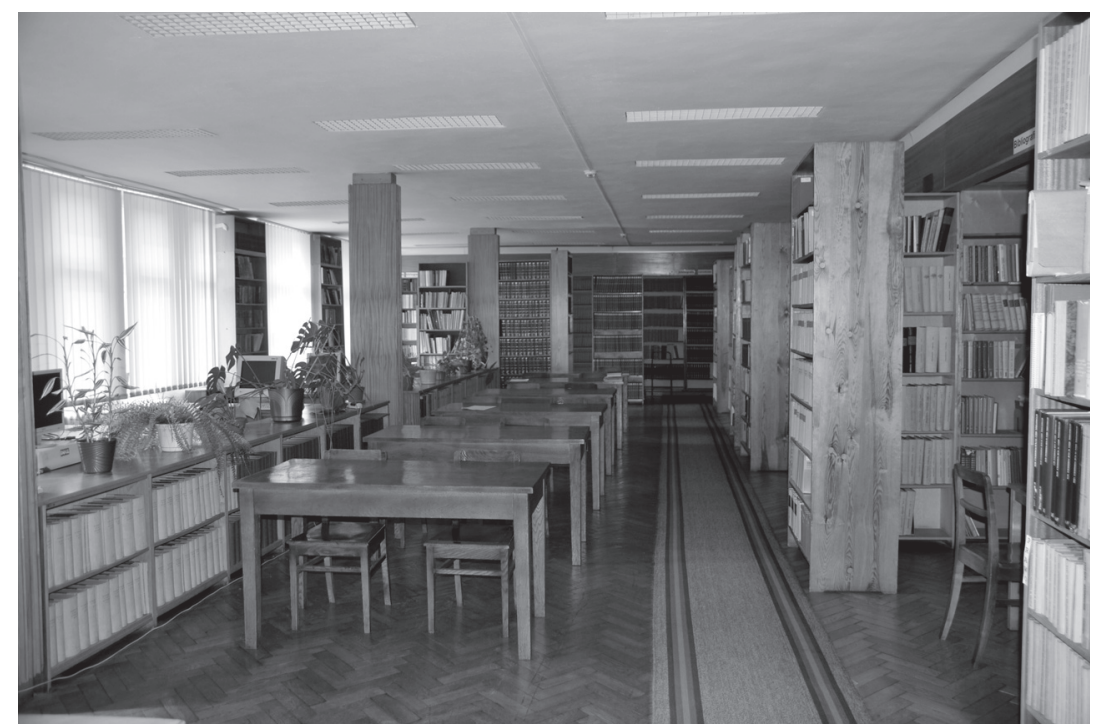

Fot. 9. Czytelnia Profesorska (ob. Informacji Naukowej) na I piętrze, $2016 \mathrm{r}$. Fot. Arkadiusz Adamczuk.

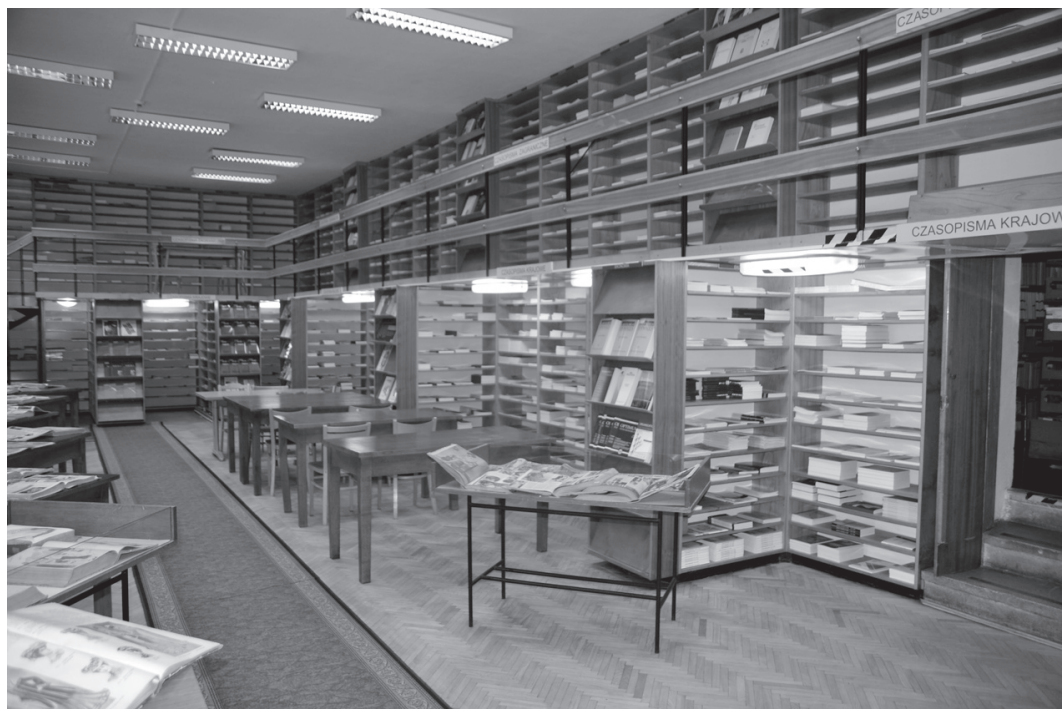

Fot. 10. Czytelnia Czasopism na parterze, $2016 \mathrm{r}$. Fot. Arkadiusz Adamczuk. 


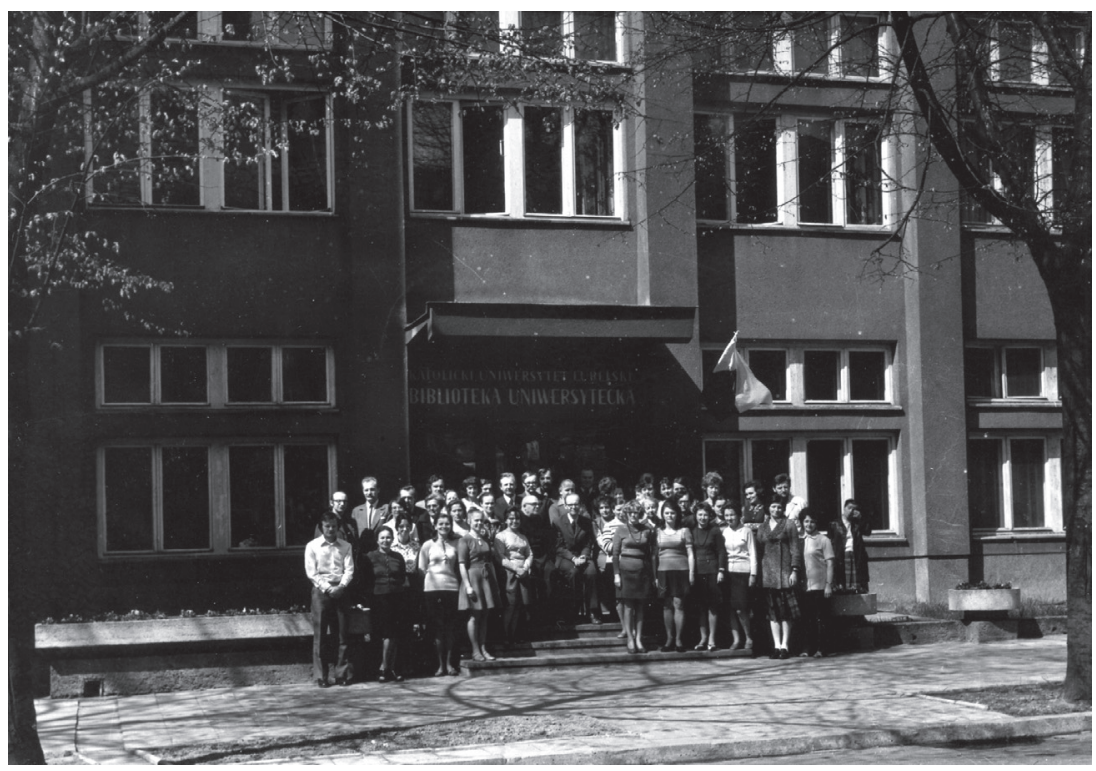

Fot. 11. Pracownicy i dyrekcja Biblioteki KUL, przed głównym wejściem przebudowanego gmachu, 1974 r. Zbiory autora.

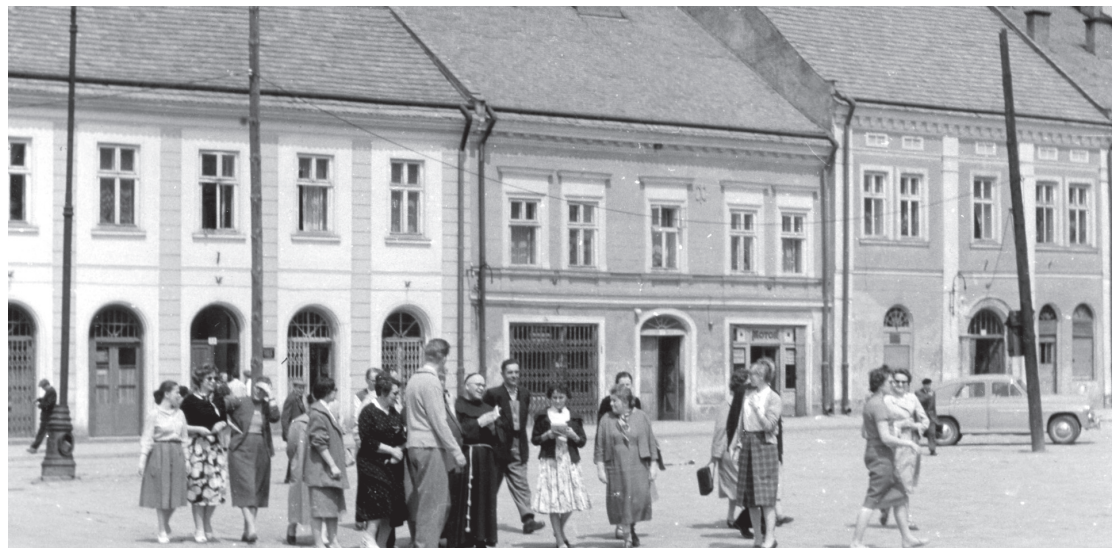

Fot. 12. O. R. Gustaw na wycieczce pracowników Biblioteki KUL, ok. 1960 r. Zbiory autora. 


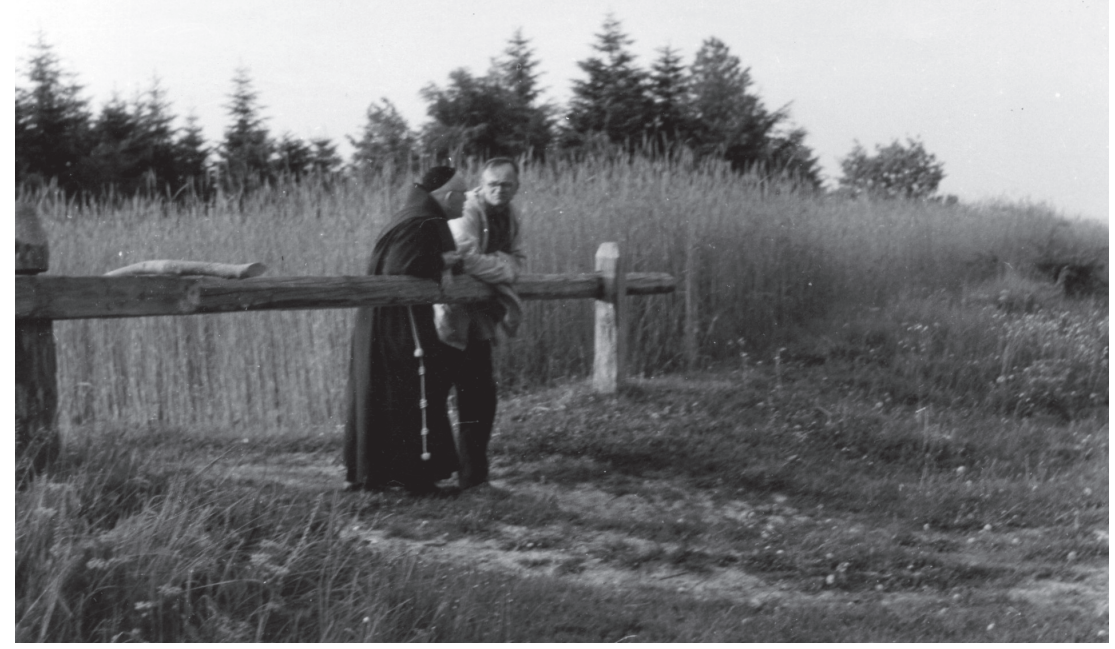

Fot. 13. O. R. Gustaw z wicedyrektorem Janem Wiślińskim, uczestnikiem przebudowy Biblioteki KUL w latach 1947-1950, w czasie wycieczki w Bieszczadach, ok. 1960 r.

Zbiory autora.

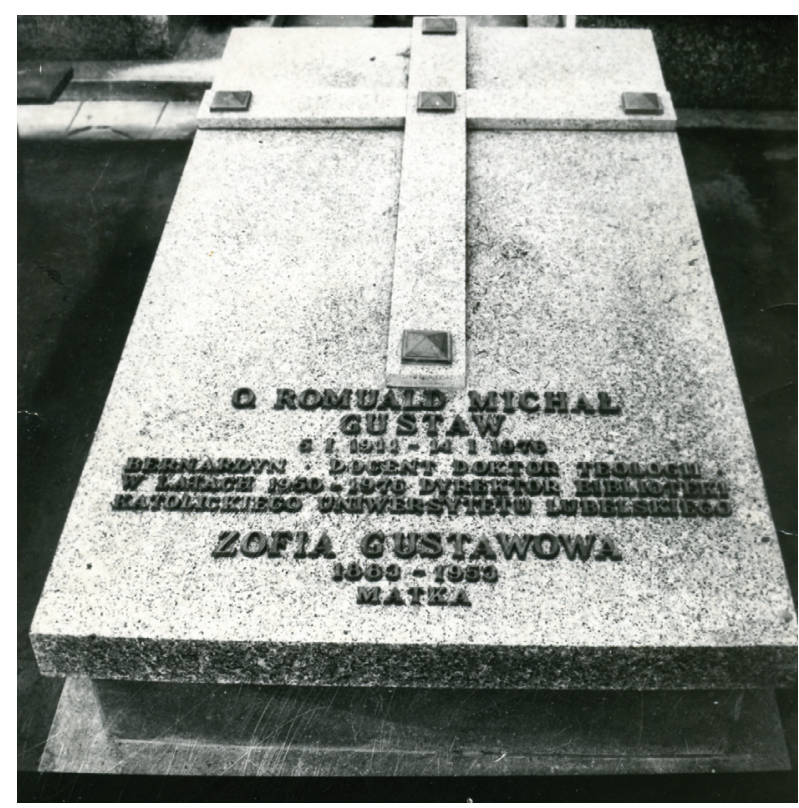

Fot. 14. Płyta nagrobna o. R. Gustawa na cmentarzu przy ul. Lipowej w Lublinie, ok. 1978 r. Zbiory autora. 